Horizons, 45, pp. 375-411. (C) College Theology Society, 2018

doi:10.1017/hor.2018.74

\title{
THEOLOGICAL ROUNDTABLE
}

\author{
Shared Communion
}

This theological roundtable discussion on shared communion, presented at the 2018 CTS Convention, reflects twenty-plus years of conversations among theologians: some Catholic, members of the College Theology Society; and some Baptist, members of the National Association of Baptist Professors of Religion, region-at-large. They gather at the annual convention of the College Theology Society not only for intellectual exchange but also for common prayer. Over the decades, the Baptist theologians have always participated in Mass. Their fidelity informed Sandra Yocum's presidential address at the convention, which began with a lament over our Christian disunity reflected in the faces of my dear friends in Christ, these Baptist theologians who with all humility process with the other communicants, but with arms crossed over their chests to signal that they cannot receive Christ, whom they too believe to be present in the sacrament. ${ }^{1}$ The lament sparked a desire in Curtis Freeman to respond with this careful study of the rules among Baptists and Catholics for intercommunion. The subsequent thoughtful responses from Catholics and Baptists bring to the foreground the painful reality of Christ's wounded Body that neither refraining from nor participating in the Eucharist will fully resolve. Yet, each respondent affirms hope in the Eucharist's healing power and echoes Christ's own prayer "that they may all be one, as you, Father, are in me and I in you" (John 17:21).

Keywords: ecumenism, eucharistic theology, intercommunion, Lord's Supper, BaptistCatholic dialogue

\section{Can Catholics and Baptists Share Communion without Breaking the Rules?}

The National Association of Baptist Professors of Religion (NABPR) first began attending the College Theology Society (CTS) convention in 1996. That meeting was held at the University of Dayton. Many of the

${ }^{1}$ For the presidential address delivered at the 2014 convention, see Sandra Yocum, "Learning What Your Face Is Like," Horizons: The Journal of the College Theology Society 41, no. 2 (December 2014): 329-39.

Curtis W. Freeman, PhD, is Research Professor of Theology and Baptist Studies at Duke Divinity School and director of the Baptist House of Studies. His research and teaching explores areas of Free Church theology. His most recent book is Undomesticated Dissent: Democracy and the Public Virtue of Religious Nonconformity (Baylor University Press, 2017). He is an ordained Baptist minister and serves as editor of the American Baptist Quarterly and on the Baptist World Alliance Commission on Doctrine and Christian Unity. 
Baptists came at the urging of James McClendon, who had been the doctoral supervisor of Terrence W. Tilley, then the chair of the Religious Studies Department at the University of Dayton and CTS president. The plan to get the Baptists to start coming to this meeting was a joint effort. It is not surprising that McClendon would look to Catholics as conversation partners about the sort of theology he and (he hoped) other Baptists would be doing. He was an odd sort of Christian-a catholic Baptist, as we would later call it. ${ }^{2}$ Raised a Southern Baptist in Louisiana, he became the first Protestant theologian hired by a Catholic theology department, at University of San Francisco, after he lost his teaching post at a Southern Baptist seminary for supporting civil rights. The ecumenical experiment, however, did not last long, as his contract was mysteriously not renewed after he circulated a petition among the faculty denouncing the Vietnam War. McClendon quickly wore out his welcome, as we say in the South, having not yet learned the unspoken rule among Catholics, "Don't mess with Jesuits." He would not make the same mistake again, though in his continued peregrinations he found that he could spar more freely with members of the Congregation of the Holy Cross, Franciscans, or Marianists.

On Saturday evening of that CTS convention in Dayton, we found ourselves attending Mass. As we Baptists made our way forward to the altar, one by one we crossed our arms signaling that we wished to receive a blessing rather than asking to be communed. Though we lacked any knowledge of canon law, we understood (or at least we thought we understood) enough to know that Protestants and Catholics do not intercommune. But when McClendon came forward, instead of crossing his arms, he held out his hands, and received the elements. Afterward, I said, "Jim, you know the rules." He nodded, and then said with a playful tone, "Some rules were meant to be broken." No doubt his characteristic willingness to break rules was rooted in his Baptist independence, and to something he had come to call "conviction" and "character." 3 He was, in my designation, an "undomes-

${ }^{2}$ Curtis W. Freeman, "A Confession for Catholic Baptists," in Ties That Bind: Life Together in the Baptist Vision, ed. Gary A. Furr and Curtis W. Freeman (Macon, GA: Smyth \& Helwys, 1994), 83-97; Freeman, Contesting Catholicity: Theology for Other Baptists (Waco, TX: Baylor University Press, 2014), 389; and Steven R. Harmon, Towards Baptist Catholicity (Milton Keynes: Paternoster, 2006), 3.

${ }^{3}$ James Wm. McClendon Jr. and James M. Smith, Understanding Religious Convictions (Notre Dame: University of Notre Dame Press, 1975); Convictions: Defusing Religious Relativism, rev. ed. (Valley Forge, PA: Trinity Press International, 1994); McClendon, Biography as Theology: How Faith Stories Can Remake Today's Theology (Nashville: Abingdon Press, 1974); rev. ed. (Philadelphia: Trinity Press, 1990), 13-38. 
ticated dissenter" if ever there was one. ${ }^{4}$ In an article published in 1967, which reflects his early struggle to stand up against the rules in Baptist and Catholic institutions, McClendon asserted that "we must be free to speak and act according to conscience as conscience is enlightened by our learning." ${ }^{5}$ His more mature thinking followed the revival of virtue ethics and narrative theology in the writings of Alasdair MacIntyre, Stanley Hauerwas, and John Yoder, which led him to reject both the rule theory of ethics in its Kantian and Reformed iterations, and consequentialism in its varieties of utilitarian and situation ethics. ${ }^{6}$

McClendon's understanding of the ways that rules operate in theological discourse was informed by Wittgenstein and other game theorists. Some rules are arbitrary additions that may become associated with the game, but are not integral to it. Other rules function like general principles or "rules of thumb," which are to be followed prima facie, all things being equal. But neither one of these types of rules is necessarily internal to and constitutive of the practice itself. There are, however, other rules that are not arbitrary additions that can be discarded in actual play or even general principles that may be set aside. Some rules actually constitute the game and make it what it is. Such rules are internal to and constitutive of the practice. Constitutive rules cannot be broken because they make the practice what it is. Indeed, to break constitutive rules is to refuse to play the game and to play a new game. ${ }^{7}$ It is important then to ask what McClendon might have meant when he suggested that "some rules were meant to be broken." It is highly likely given my complete ignorance of Catholic canon law at the time that my sense of what comprised "the rules" was ill conceived and insufficiently nuanced.

The desire to share table fellowship follows the directives of the Faith and Order Commission of the World Council of Churches at Louvain, which urged all Christians to follow their ecumenical commitments in working "towards full eucharistic communion," but to do so in accordance with their rules and discipline. ${ }^{8}$ Of those who might be inclined to take up this challenge, Catholics and Baptists would seem to be the least likely to do so. But stranger

${ }^{4}$ My book Undomesticated Dissent: Democracy and the Public Virtue of Religious Nonconformity (Waco, TX: Baylor University Press, 2017) is dedicated to James McClendon.

5 James Wm. McClendon Jr., "Academic Freedom Is Student Freedom," Baptist Student 46, no. 7 (April 1967): 28-29.

${ }^{6}$ James Wm. McClendon Jr., "Three Strands of Christian Ethics," Journal of Religious Ethics 6, no. 1 (1978): 54-80; McClendon, Systematic Theology, vol. 1, Ethics (Waco, TX: Baylor University Press, 2012), 70-74.

7 McClendon, Ethics, 170.

${ }^{8}$ Beyond Intercommunion, Faith and Order Paper No. 59 (Geneva: World Council of Churches, 1971), 223. 
things have happened. When US President Bill Clinton, a Southern Baptist, visited Soweto, South Africa, in 1998, both he and his United Methodist wife were given Holy Communion; afterward, the Catholic bishops of South Africa were rebuked by the Vatican and asked to revise their ecumenical directory. ${ }^{9}$ The minister of the American Baptist congregation of which I am a member has for many years convened for an annual retreat with several other ordained Baptist women in a house for Catholic women religious. She and her Baptist colleagues are received at the Eucharist, and some of the sisters even commune when the Baptist women preside at the Lord's Supper. No doubt some would say that these are exceptions that simply prove the rule, which may be right. Nevertheless, we find ourselves asking under what conditions we might consider sharing intercommunion without breaking the rules. In framing the question like this I am asking what rules constitute the eucharistic practice in which Baptists and Catholics might share, and whether we can participate in eucharistic sharing without breaking those rules.

\section{The Rules of Baptist Practice for Communion}

For Baptists like McClendon, the constitutive rule of eucharistic practice is the rule of Christ. ${ }^{10}$ Its observance can be traced to the earliest days of

9 James Bennet, "President Took Communion and Criticism," New York Times, April 7, 1998. The White House reported that Father Mohlomi Makobane communicated that, according to the policy of the South African Catholic Bishops' Conference, communion was open to non-Catholics. The South African Directory on Ecumenism at the time stated that when non-Catholic Christians attend a Eucharist for "a special feast or event," sharing communion "may be both meaningful and desirable, expressing the degree of unity that the participating Christians already have with each other." Directory on Ecumenism for Southern Africa, VI.B.3, published in Catholic News Service, February 26, 1998, 606-610, https:// www.catholicculture.org/culture/library/view.cfm?recnum=293. The Revised Directory was published by the Southern African Catholic Bishops' Conference in January 2000. The revised section on eucharistic intercommunion (6.3.2) reads: "The general rule flowing from these principles is therefore that abstinence from shared sacramental worship is the normal state of affairs but circumstances can exist in which such a sharing becomes not only permissible but commendable. As the Directory for the Application of the Principles and Norms on Ecumenism expresses it: 'In general the Catholic Church permits access to its Eucharistic communion and to the sacraments of penance and anointing of the sick, only to those who share its oneness in faith, worship and ecclesial life. For the same reasons, it also recognizes that in certain circumstances, by way of exception, and under certain conditions, access to these sacraments may be permitted, or even commended, for Christians of other Churches and ecclesial Communities'" https://www.catholicculture.org/culture/library/view.cfm?recnum=2746.

${ }^{10}$ John Howard Yoder, "Binding and Loosing" and "Sacrament as Social Process," in The Royal Priesthood: Essays Ecclesiological and Ecumenical, ed. Michael G. Cartwright (Grand Rapids, MI: Eerdmans, 1994), 323-73. 
the Baptists. ${ }^{11}$ Even though it has sometimes faded in the collective memory, the rule has remained constitutive of communion practice among Baptists. McClendon learned to notice the operation of this rule through his engagement with the Anabaptist tradition. According to the rule of Christ, the Lord's Supper (as it is most often called) is to be observed by those who have deliberately committed themselves to live as faithful followers of Jesus Christ. It finds classic expression in the first article of the confession of faith affirmed by the Taufer (Baptists) gathered in Schleitheim, Switzerland, in 1527, which declares:

Baptism should be given to all who have learned repentance, amendment of life, and faith through the truth that their sin has been removed by Christ; to who want to walk in the resurrection of Jesus Christ and to be buried with him in death so that they can be resurrected with him; and to all who desire baptism in this sense from us and who themselves request it. ${ }^{12}$

The article continues, adding that baptism was to be administered to disciples, thus excluding infant baptism, which they regarded as "the greatest and first abomination of the pope." It was an oft-repeated refrain among Baptists, beginning with the first Baptist, John Smyth, who pronounced infant baptism to be the mark of the Beast of Revelation 13:16-17. The church of Jesus Christ, Smyth argued, is truly constituted in baptism of "those that are made disciples by teaching, [people] confessing their faith and their sins." ${ }^{13}$ The earliest Baptists traced their views to an early Christian tradition voiced by Tertullian, who recommended postponing baptism until a candidate has "become competent to know Christ." 14 As McClendon states, "Baptism is reserved for those who commit themselves to Christ in active faith, and who come to express that faith by entering the waters of the baptistry." ${ }^{15}$

${ }^{11}$ William G. McLoughlin, Soul Liberty: The Baptists' Struggle in New England, 1630-1833 (Providence: Brown University Press, 1991), 37-92, esp. 63-72; and James Leo Garrett Jr., Baptist Church Discipline (Nashville: Broadman, 1962).

12 The Schleitheim Articles, $\$ 1$, in The Radical Reformation, ed. Michael G. Baylor (Cambridge: Cambridge University Press, 1991), 174.

${ }^{13}$ John Smyth, The Character of the Beast, in The Works of John Smyth, ed. W. T. Whitley (Cambridge: Cambridge University Press, 1915), 2:565.

${ }^{14}$ Tertullian, Baptism 18.5, in Tertullian's Homily on Baptism, trans. Ernest Evans (London: SPCK, 1964), 39. Tertullian, Apology 18, in the Ante-Nicene Fathers of the Church (New York: Christian Literature Publishing Co., 1885), 3:32.

${ }^{15}$ James Wm. McClendon Jr., "Why Baptists Do Not Baptize Infants," in The Sacraments: An Ecumenical Dilemma, ed. Hans Küng (New York: Paulist Press, 1966), 7. 
The rule of Christ places an emphasis on the baptismal candidate's readiness to submit to the mutually reciprocal and communally discipling process as set forth in Matthew 18:15-20. The underlying ecclesiology is based on the covenant between God and the church (i.e., the vertical covenant) and between the members of the church as the covenant community (i.e., the horizontal covenant). ${ }^{16}$ The Baptist Faith and Message (1925/1963) gestures to this covenantal ecclesiology, describing a church as a "body of baptized believers who are associated by covenant in the faith and fellowship of the gospel, observing the two ordinances of Christ" (i.e., baptism and the Lord's Supper). ${ }^{17}$ Within this framework of covenantal theology, baptism is understood as a performative act that signifies God's once-and-for all reconciling work in Jesus Christ, and the Lord's Supper is a performative act of reconciliation whereby the covenant with God (i.e., the vertical covenant) and with one another (i.e., the horizontal covenant) is renewed. ${ }^{18}$ While this account of the Lord's Supper lays stress on the practice in the local church, it offers the promise of an ecumenical vision by conceiving of an ecclesial openness to and a historical continuity with the whole covenant people of God throughout the world and the ages. ${ }^{19}$

The rule of Christ governs the observance of the Lord's Supper as a reconciling practice so that it serves as a powerful sign of unity with the community gathered around the table and with the whole church of Christ. Yet because Christians who gather around the table are not always of one accord, Matthew 18:15-20 provides a process of forgiveness and reconciliation so that baptized Christians may come to the table to be nourished and sustained in their union with Christ and with one another. The observance of the Lord's Supper as a reconciling practice according to the rule of Christ is described in the Sermon on the Mount, which gives specific instructions about the process of seeking forgiveness and reconciliation. It states:

${ }^{16}$ Champlin Burrage, The Early English Dissenters in Light of Recent Research (Cambridge: Cambridge University Press, 1912), 1:314 and 2:294.

17 The Baptist Faith and Message, VI, in William L. Lumpkin, Baptist Confessions of Faith, rev. ed. (Valley Forge, PA: Judson Press, 1969), 396.

${ }^{18}$ William Kiffin, A Sober Discourse of Right to Church-Communion (London: George Larkin, 1681), 103.

19 Paul S. Fiddes, Tracks and Traces: Baptist Identity in Church and Theology (Carlisle, UK: Paternoster, 2003), 24. In his introduction to the international Baptist-Catholic dialogue (2006-10), Fiddes pointed to ecumenical potential for thinking about the "ever-widening circles of covenant, in a way that is more directly grounded in the whole people of God." "A Conversation in Context: An Introduction to the Report The Word of God in the Life of the Church," American Baptist Quarterly 31 no.1 (2012): 13. See the Report, $\$ \$ 16$ and 20, pp. 40-41. 
So when you are offering your gift at the altar, if you remember that your brother or sister has something against you, leave your gift there before the altar and go; first be reconciled to your brother or sister, and then come and offer your gift. (Matt 5:24-25)

If there are matters that stand between members of the community gathered around the Lord's table, those who are alienated from one another are instructed to make peace and be reconciled to one another before sharing in the breaking of bread. One of the most widely and longest-used church covenants among Baptists in the United States, often recited in unison before the observance of communion, declares the commitment "to watch over one another in love" and "always [be] ready for reconciliation" according to the rule of the Savior (Matt 18:15-20). ${ }^{20}$

The majority view among earlier generations of Baptists linked baptism and the Lord's Supper, so that table fellowship was restricted to those who were "regularly baptized" by immersion upon the confession of their faith. According to this practice of closed communion, infant baptized believers were excluded from table fellowship. The Baptist Faith and Message through all its revisions has never wavered from the declaration that a believer's baptism by immersion "is prerequisite to the privileges of church membership and to the Lord's Supper." ${ }^{21}$ From the earliest days of the Baptists, however, there was a minority view, which held that baptism should not be regarded as a condition for communion at the Lord's table. This practice of open communion permitted infant baptized (and sometimes even unbaptized) believers to participate in the Lord's Supper. ${ }^{22}$

When McClendon shared table fellowship with infant baptized Catholics, did he break the Baptist rules of communion, and specifically the rule of

${ }^{20}$ J. Newton Brown, The Baptist Church Manual (Philadelphia: American Baptist Publication Society, 1853), 23-24. The version published in the National Baptist Hymnal adds "in the eighteenth chapter of Matthew."

${ }^{21}$ Baptist Faith and Message (1963/200o), 7; for the 1963 version of BFM, see Lumpkin, Baptist Confessions of Faith, 396; for the 2000 version of the BFM, see http://www.sbc. net/bfm200o/bfm200o.asp. The 1925 confession similarly states that believer baptism by immersion is "prerequisite to the privileges of a church relation and to the Lord's Supper." Baptist Faith and Message (1925), 13; see Robert A. Baker, A Baptist Source Book (Nashville: Broadman, 1966), 202.

22 The most well-known open communionist was John Bunyan, A Confession of My Faith, and a Reason of my Practice, in The Works of John Bunyan, ed. George Offor (Glasgow: W. G. Blackie \& Son, 1854), 2:606; and Bunyan, Differences in Judgement about WaterBaptism, ibid., 2:617. Bunyan was part of a much wider community among the earliest English Baptists who practiced open communion to those who were not believer baptized. See Curtis W. Freeman, Contesting Catholicity, 348-55. 
Christ? For him the constitutive rules of communion surely had more to do with whether the communion involved the words of institution (paradosis), the remembrance of Jesus (anamnesis), and the invocation of the Spirit (epiclesis-paraclesis). ${ }^{23}$ From the standpoint of closed communion the answer would seem to be a clear violation. But McClendon was not a closed communionist, nor were the other Baptists attending Mass at the CTS convention in 1996 or in subsequent years. Indeed, only about one-third of Southern Baptists now practice closed communion restricted to believer baptized Christians. ${ }^{24}$ McClendon, and probably all of the NABPR members who have attended the CTS convention through the years, hold an open communion view by conviction and practice.

Determining how the practice of open communion works according to the rules requires additional explanation. Though the rule of Christ is constitutive of Baptist practice for the Lord's Supper, it is not the only rule. It is complemented and qualified by what McClendon and others called "the rule of Paul," which is a way of seeking unity, not by majority vote, but by congregational discernment in which every voice is heard and none is silenced (1 Cor 14:29-33). Key to this social process of communion is the conviction of respecting the conscience of each believer who walks according to the light he or she has received. It is a way of discernment that attends to and respects matters of conscience (Rom 2:15, 9:1, 13:5). Where the rule of Christ commands Christians to be reconciled to God and one another before observing communion, the rule of Paul commends the gathered community to discern the body before communing. Such a process leads beyond majority rule toward consensus and ultimately the mind of Christ (Phil 2:5).25

Prior to celebrating the communion meal, the gathered are urged not to participate in an unworthy manner. They are challenged to examine themselves and to discern the body (1 Cor 11:27-28). And, as in the rule of Christ, if there is a matter between them, and between them and the Lord, they are to seek reconciliation and forgiveness before coming to the table (Matt 5:24-25; 1 Cor 11:33-34). The fact that we Baptists so often eat and drink without discerning the Lord's body, that is, without discerning our union with Christ and with one another in Christ, means that, in the words

23 Freeman, Contesting Catholicity, 329.

24 According to a poll conducted by LifeWay Research, more than half ( 52 percent) of SBC pastors stated that any professing believer can participate in communion. Only a third of those polled (35 percent) stated that believer baptism is prerequisite to the Lord's Supper. Carol Pipes, “Lord's Supper: LifeWay Surveys Churches' Practices, Frequency," Baptist Press, September 17, 2012, http://www.bpnews.net/38730.

25 John Howard Yoder, Body Politics: Five Practices before the Watching World (Scottdale, PA: Herald, 1992), 70. See also Freeman, Undomesticated Dissent, 219-20. 
of Saint Paul, we eat and drink to our damnation (1 Cor 11:29). The lack of following an intentional and deliberate process of discernment, forgiveness, and reconciliation is surely a cause of the spiritual morbidity and mortality that exists in our churches (1 Cor 11:30).

Open communionists share the view that "baptism upon personal profession of faith is the most clearly attested pattern in the New Testament documents." ${ }^{26}$ They regard the baptism of believers as a normative practice, but they refuse to make baptism a bar to communion out of respect for the conscience of infant baptized Christians who believe their baptism to be genuine. ${ }^{27}$ Consequently, open communionists refuse to compel infant baptized Christians to be "rebaptized" contrary to their conscience in order to come to the Lord's table. They refuse on grounds that to force a fellow Christian to act contrary to conscience is $\sin$ (1 Cor 8:12; Rom 14:23). So, from the standpoint of the Baptist rules of open communion, McClendon's intercommunion at a Catholic Eucharist did not break the rules, nor would it break the rules of Baptist communion practice for other Baptists to share in the breaking of bread with Catholics at the Lord's table.

\section{The Rules of Catholic Practice for Communion}

Understanding the rules for Catholic intercommunion and their application in ecumenical settings is more complicated than it is for Baptists. The door of eucharistic hospitality to "separated brethren" was cracked open at Vatican II in paragraph 8 of the Decree on Ecumenism (Unitatis Redintegratio). The decree commends the work of "spiritual ecumenism" to be carried out in services of prayer, which it states are "a very effective means of petitioning for the grace of unity." Yet common worship is not to be entered into indiscriminately because the sacraments are signs of the unity of the church and sources of grace. Indiscriminate intercommunion may actually weaken the church's unity, becoming an instrument of spiritual injury rather than a source of sacramental vitality. While it is important to note that the lack of ecclesial unity in general makes intercommunion a questionable option, the grace to be obtained thereby may in some instances

26 Baptism, Eucharist and Ministry IV.A.11, Faith and Order Paper No. 111 (Geneva: World Council of Churches, 1982), 4.

${ }^{27}$ For an account of the open communion view in the Jessey-Bunyan tradition, see Freeman, Contesting Catholicity, 35-55. The evangelical tradition that predominates in Southern Baptist faith and practice today frames the open communion rules in terms of whether one who comes to the table has "accepted Christ," thus making an evangelical conversion experience, not believer baptism, the primary condition for admission to the table. 
commend it. The possibility of intercommunion, though regarded to be unusual and exceptional, is not strictly prohibited or ruled out. The act of extending the means of grace by opening sacramental communion to nonCatholics is a prudential decision normally left to the diocesan bishop or the episcopal conference, rather than a prescriptive matter decided in principle. ${ }^{28}$

Three years after the Second Vatican Council's Decree on Ecumenism, the Vatican Secretariat for the Promotion of Christian Unity (SPCU), now the Pontifical Council for Promoting Christian Unity (PCPCU), issued an Ecumenical Directory to guide bishops in their prudential judgments. It states that because the sacramental unity of the faith is deficient among Protestants, Catholics are forbidden from participation in their services of sacramental worship. However, the communion of Protestants in a Catholic Eucharist may be permissible under certain circumstances. The Ecumenical Directory specified four conditions for the communion of Protestants:

(1) They must have no access to a minister in their own ecclesial community.

(2) They must spontaneously ask for the sacrament of their own initiative.

(3) They must express a eucharistic faith in harmony with the Catholic Church.

(4) They must manifest a right disposition. ${ }^{29}$

These conditions were offered as guidelines to be followed, not advisory principles that could be ignored. The formulation of these conditions was based on the standing interpretations prescribed in canon law and the state of ecumenical theology at the time. They were not regarded as fixed ecumenical policy, nor did they preclude the possibility of further development in the future. The Ecumenical Directory left room in determining circumstances that might call for extraordinary communion. The danger of death, persecution, and imprisonment were noted as three examples when the communion of Protestants might be considered. The determination and adjudication of other cases of "urgent need" were left to the pastoral judgment of local bishops or episcopal conferences with the understanding that all four

${ }^{28}$ Unitatis Redintegratio, §8, in Vatican Council II: Volume 1, The Conciliar and Post Conciliar Documents, new rev. ed. (New York: Costello, 2004), 461.

29 "Directory Concerning Ecumenical Matters," Part I, IV.C.2.55, in Doing the Truth in Charity: Statements of Pope Paul VI, Pope John Paul II, and the Secretariat for Promoting Christian Unity, ed. Thomas F. Stransky and John B. Sheerin (Ramsey, NJ: Paulist Press, 1982), 41-57. 
conditions applied in all exceptional cases of eucharistic communion with Protestants.

The Second Vatican Council's Decree on Ecumenism inspired ecumenically minded Catholics and Protestants to explore the possibilities of moving beyond intercommunion or partial communion toward the goal of full eucharistic communion. In 1970 the Faith and Order Commission of the National Council of Churches (NCC) sponsored two meetings to study the topic "The Eucharist and the Ecumenical Movement." Participants included representatives from Catholic, Orthodox, Episcopal, Lutheran, Presbyterian, Methodist, Disciples of Christ, United Church of Christ, Baptist, Brethren, and Quaker traditions. The commission produced a consensus statement that sought to express in broad terms what all Christians believe about the Eucharist. The chair of the group, Harry J. McSorley, a Catholic theologian, confidently announced the statement to have reached "unprecedented agreement" on "the meaning of the Eucharist," adding that as a result of their findings "most of the traditional disagreements among various churches are no longer theologically necessary." Drawing from the language of recent ecumenical materials on eucharistic intercommunion, the statement affirmed that the symbols and symbolic actions in the Lord's Supper are "effective signs" that "make Christ present" with his people. ${ }^{30}$

Avery Dulles, another Catholic theologian who participated in the study group, explained that they deliberately avoided contested terms of the past that do not resonate in the contemporary world, admitting that "the particular word 'transubstantiation' was no longer used by Catholic theologians," although one of the Catholic theologians tasked with evaluating it declared that the consensus statement was "quite compatible with the dogma of transubstantiation." ${ }^{11}$ The statement confidently declared that "the power of the Spirit through the Word makes Christ really present throughout the eucharistic action in his body and blood." It further urged continued work to

${ }^{30}$ Harry J. McSorley, "Unprecedented Agreement on the Eucharist," The Ecumenist 8, no. 6 (September-October 1970): 89-90; "The Eucharist and the Ecumenical Movement," §8, American Ecclesiastical Review 164, no. 2 (Feb. 1971): 137-42; and The Ecumenist 8, no. 6 (September-October 1970): 90-93; Edward B. Fiske, "Catholic and Protestant Group Sees Rise in Sharing Communion," New York Times, Dec. 15, 1970, 41. Catholic participants in the NCC study group included Sister Sara Butler (College of Wooster), Avery R. Dulles, SJ (Woodstock College), Richard P. McBrien (Boston College), Harry J. McSorley (St. Michael's College), Daniel J. O'Hanlon, SJ (Jesuit School of Theology, Berkeley), and Carl Peter (Catholic University of America). The only Baptist was Franklin Segler (Southwestern Baptist Theological Seminary).

${ }^{31}$ Cited in Fiske, "Catholic and Protestant Group," 41. Carl J. Peter, "The Eucharist and Christianity as the Way in the Future," American Ecclesiastical Review 164, no. 6 (June 1971): 400. 
overcome the barriers to mutual recognition of various eucharistic communities because division on this matter obscures the catholicity of the Eucharist. The American Ecclesiastical Review, the monthly periodical of the Catholic University of America, which published the consensus statement, devoted an entire issue to a deeper analysis of it with articles from five representatives of the traditions that comprised the commission's working group. Two of the participants who wrote evaluative essays, one Orthodox and the other Quaker, offered critical retractions, but the Lutheran, Congregational, and Catholic respondents were highly supportive, praising it for crossing new frontiers in ecumenical theology. ${ }^{32}$

In 1970, the same year that the NCC working group held their meetings, the SPCU issued a declaration on the possibility of reconsidering the ecumenical norms for intercommunion put forward in the 1967 Ecumenical Directory. The declaration commended the desire for eucharistic communion as a stimulus for "perfect ecclesial unity among all Christians," expressing "gratitude for the partial unity already obtained," "regret for the divisions which still remain," and "firm resolve to do everything possible to overcome them." But in the end it suggested that the desire for full communion finds appropriate expression in services of common prayer that do not involve the possibility of ecumenical intercommunion. ${ }^{33}$

The declaration did not settle the matter. Two years later the SPCU produced an instruction, which directly addressed the question "In what circumstances and on what conditions can members of other churches and ecclesial communities be admitted to eucharistic communion in the Catholic Church?" The SPCU was troubled about what to do regarding Christians "who are not in full communion with the Catholic Church" and do not "have recourse to the ministers of their own communities, as their conscience dictates." The secretariat wondered what was to be done about them when they "ask for communion from a Catholic priest." The first guiding principle governing admission to sacramental communion is the signification of "the fullness of profession of faith and the fullness of ecclesial communion." The Instruction continued that this principle will not be obscured if admission to Catholic eucharistic communion is confined to particular cases of those Christians,

(1) who have a faith in the sacrament in conformity with that of the [Catholic] Church,

(2) who experience a serious spiritual need for the eucharistic sustenance,

32 American Ecclesiastical Review, 164 no. 6 (June 1971): 363-417.

33 "The Position of the Catholic Church Concerning a Common Eucharist between Christians of Different Confessions," \$9, in Doing the Truth in Charity, 117-21. 
(3) who for a prolonged period are unable to have recourse to a minister of their own community,

(4) who ask for the sacrament of their own accord, and

(5) who have proper dispositions and lead lives worthy of a Christian. ${ }^{34}$

These conditions repeated the four of the Ecumenical Directory, but added the broader circumstance of "a need for an increase in spiritual life and a need for a deeper involvement in the mystery of the Church and of its unity." The Instruction worried that admitting Christians from ecclesial communities whose eucharistic faith differs from Catholic teaching risked endangering the first guiding principle of "obscuring the essential relation between eucharistic communion and ecclesial communion." But even given this risk, the secretariat advised that such Christians should not be excluded from eucharistic communion if in the judgment of episcopal authorities they qualify under the conditions of exceptional cases.

The instruction was followed the next year with further advice from the SPCU in the Note Concerning Certain Interpretations of the 'Instruction.' The Note cautioned that eucharistic communion with Christians not in full ecclesial communion cannot express the full unity of the Eucharist and "for this reason such communion cannot be regarded as a means to be used to lead to full ecclesial communion." The Instruction nevertheless allowed for pastoral exceptions to be made by episcopal judgment, reiterating the conditions laid out in the Instruction. The Note on the Instruction further advised that exceptions were to be determined on a case-by-case basis left to the local episcopal authority. The Note further advised that non-Catholics admitted to communion must manifest faith in the sacramental reality of Christ's presence in the Eucharist, which is "not limited to a mere affirmation of the 'real presence' in the Eucharist, but implies the doctrine of the Eucharist as taught in the Catholic Church."35 The 1975 SPCU document Ecumenical Collaboration at the Regional, National, and Local Levels brought to a close the series of Vatican initiatives offering guidance and direction on discussions about ecumenical inclusion of non-Catholics in Catholic eucharistic communion. ${ }^{36}$

34 "Cases When Other Christians May Be Admitted to Eucharistic Communion in the Catholic Church," $\$ \S 1$ and 4, in Doing the Truth in Charity, 122-26 (emphasis added by author).

35 “Concerning Certain Interpretations of the 'Instruction'," $\$ \$ 4$ and 7, in Doing the Truth in Charity, 126-28.

36 "Ecumenical Collaboration at the Regional, National, and Local Levels," in Doing the Truth in Charity, 89-114. 
Progressive Catholic theologians continued to press for greater reform. In 1970, the same year as the NCC consensus statement on the Eucharist, Harry McSorley, chair of the working group that produced the statement, wrote an article on "eucharistic sharing" for the Ecumenical Review, which expressed the hopes of theological progressives seeking fuller communion between Catholics and Protestants. He described how developments in Faith and Order, the Consultation on Church Union (started in 1962 as an ecumenical effort aimed at institutional expressions of church union in the United States), and bilateral dialogues, along with the work of ecumenical theologians, had changed Catholic views on the subject since Vatican II. ${ }^{37}$ McSorley noted that while it was not correct to speak about an ecumenical consensus regarding eucharistic communion, it was possible to describe a growing convergence. McSorley reported that a number of Catholic theologians had offered suggestions for broader eucharistic sharing than imagined in the 1967 Ecumenical Directory. These proposals included calls for the (1) relaxation of the double standard for eucharistic sharing that treats Orthodox and Protestants differently, (2) revision of the grounds for admitting Protestants in eucharistic communion from "urgent cases" to "sufficient reason" of a need for a deeper involvement in the mystery of the church and of its unity, (3) permission for non-Catholic partners in interconfessional marriages to receive the Eucharist at the marriage mass, (4) signification and enhancement of the real though imperfect unity that exists among Christians in light of the ecumenical consensus that has been demonstrated on the theological level.

McSorley offered a set of guidelines for ecumenical communion that included (a) celebration of the Eucharist with the support, if not the actual participation, of the respective local church leaders with due regard for the church universal; (b) occasional eucharistic sharing to signify the existing unity in Christ and to deepen it; (c) a mutually agreed-upon common rite and a common confession as to the meaning of the Eucharist so that all participants are theologically and spiritually prepared; (d) an official pledge from the churches involved made public to indicate that the occasional sharing of the Eucharist is not the goal of ecumenism but only a partial communion on the way to total reconciliation; and (e) some means of assurance from Catholics on the legitimacy of co-celebrating Protestant ministers. McSorley concluded by stating that since Vatican II, Catholic thinking has undergone "radical, but theologically and historically well-grounded change on the question of eucharistic sharing." He suggested that in his view this progressive

37 Harry J. McSorley, "Eucharistic Sharing: A New State of the Question for Roman Catholics," Ecumenical Review, 22 no. 2 (1970): 113-24. 
trend represented the direction of Catholic theology, which he urged, must continue to guide "the Church and the churches to move beyond intercommunion simply to communion." 38

Avery Dulles, like McSorley, was identified with conciliar progressives, who were pushing for aggiornamento or updating the tradition. He sided with those who were open to development and reformulation of doctrine. Yet Dulles was no theological liberal. Unlike the revisionist wing of Catholic theologians, who were already pushing at the boundaries of the council, he represented the dynamic middle ground in the new orthodoxy of Vatican II concerned also with ressourcement or connection to the historic sources. He was committed to a reformulation that maintained continuity with the long catholic tradition. ${ }^{39}$ In 1977, he published "Eucharistic Sharing as an Ecumenical Problem," a chapter in his book The Resilient Church. ${ }^{40} \mathrm{He}$ noted that in its 1972 Instruction the SPCU relaxed the requirement of "urgent necessity" in favor of "serious spiritual need," which he welcomed as a small but significant shift. But he expressed concern that the Directory and subsequent Vatican clarifications were legalistic in tone, intended to restrict the discretion of local authorities, including the bishops. He suggested that the SPCU appeared to be trying to dial back to a preconciliar theology. He argued that occasional intercommunion may not necessarily be a concession to weakness, but rather "an appropriate sign of the partial but growing unity among separated churches." 41

Of the conditions outlined in the 1972 Instruction, Dulles commended the guidance that faith in the "real presence" of Christ in the Eucharist is not sufficient to demonstrate "a faith in the sacrament in conformity with that of the [Catholic] Church," adding that "a correct worshipful attitude is more important than an exact theological expression." ${ }^{42}$ Summarizing his response to the 1972 instruction, Dulles recommended liberalizing the conditions to allow or invite "disposed baptized Protestant believers who feel spiritually united to the Catholic Church and to its leaders, and who recognize the sacramental presence of the Lord in a Catholic Eucharist as Catholics do" to receive the communion in a Catholic Eucharist. ${ }^{43}$ Dulles, however, worried that excessive laxity in eucharistic sharing may be as harmful as excessive strictness. He,

\footnotetext{
38 McSorley, 124.

39 Patrick W. Carey, "Cardinal Avery Dulles, SJ, among the Theologians: A Memorial Reflection," Theological Studies 71 no. 4 (December 2010): 783.

40 Avery Dulles, "Eucharistic Sharing as an Ecumenical Problem," in The Resilient Church (Garden City, NY: Doubleday, 1977), 153-71.

41 Dulles, 158.

42 Dulles, 159.

43 Dulles, 160.
} 
therefore, recommended that penitent abstention from ecumenical intercommunion may be an appropriate and grace-filled sign of the current state of Christian disunity. He further expressed concern that the 1967 Ecumenical Directory had the chilling effect of excluding altogether Catholic participation in Protestant services of sacramental communion. In his reflections on the question of "real presence," Dulles suggested that the word "transubstantiation" need not be used. What is crucial, he argued, is the conviction that "Christ becomes substantially or objectively present in the elements themselves, which truly 'become' his body and blood." On this matter Dulles found a wide ecumenical consensus among Lutherans, Anglicans, Catholics, and some Reformed Christians. Dulles concluded that while occasional sacramental sharing between Protestants and Catholics may be permissible or even necessary, full eucharistic communion is not yet possible, adding that "we cannot eucharistically celebrate a unity we do not have." 44 He commended "reverent and prayerful abstention" as a performative act of the ecumenical pain of disunity and the desire for the unity we await as God's gift to the church.

But by the time Dulles' The Resilient Church appeared in print, the energy of conciliar progressives had begun to dissipate. Dulles was a signatory on a provocative and controversial statement simply titled "An Appeal for Theological Affirmation" in 1975, better known as "The Hartford Appeal," an antimodernist manifesto that called for the recovery of a sense of transcendence, which, it argued, makes faith and theology possible. The "Hartford Appeal" was signed by eighteen leading theologians across the denominational spectrum. ${ }^{45}$ It was followed by a book entitled Against the World for the World, which included an essay by Dulles on the future of ecumenism. ${ }^{46}$

44 Dulles, 171.

45 “The Hartford Appeal for Theological Affirmation," Worldview 18, no. 4 (April 1975): 3941, https://carnegiecouncil-media.storage.googleapis.com/files/v18_ioo4_ao1o.pdf. Signatories drew from a wide range of churches (i.e., Catholic, Orthodox, Protestant Mainline, Evangelicals), but represented a kind of centrist progressivism. They included Lutheran pastor Richard John Neuhaus, who became a Catholic and went on to found the important religious periodical First Things; Yale theologian George Lindbeck, who was one of the key voices in postliberal theology; Stanley Hauerwas, who became an influential Protestant theological ethicist; and Richard Mouw, who became president of Fuller Theological Seminary and a leading Evangelical theologian. In addition to Dulles, Catholic signatories included Ralph McInerny (University of Notre Dame), Carl Peter (Catholic University of America), Gerard Sloyan (Temple University), Bruce Vawter (DePaul University), and Robert Wilken (University of Notre Dame), a Lutheran like Neuhaus, who also subsequently became a Catholic.

46 Peter L. Berger and Richard John Neuhaus, eds., Against the World for the World: The Hartford Appeal and the Future of American Religion (New York: Seabury Press, 1976), 
Though the participants represented a wide range of theological and ecclesial commitments, they shared a common critique of the cultural captivity of the church to theocratic civil religion on the right and liberationist revisionism on the left. Dulles and other signatories were deeply concerned that secular movements and political ideologies were setting the social agenda for the churches. The same year as the "Hartford Appeal," Dulles was vice president of the Catholic Theological Society of America (CTSA). "Hartford" was not mentioned in any of the papers at the meeting, but in his plenary address the outgoing president, Luke Salm, took the opportunity to blast the "Hartford Appeal" as "dangerous." He then argued that the future for Catholic theology depended on more openness to modern thought, human experience, other religions, human potential, self-realization, social action, and human struggle. The upshot for Catholic theology was a division between centrists, who identified with the thrust of the "Hartford Appeal," and liberals/revisionists, who rejected it. ${ }^{47}$

Theological centrists like Dulles had provided much of the progressive energy for carrying out the doctrinal reformulation called for by the Second Vatican Council. After Hartford, however, new theological winds began blowing. The ecumenical momentum that had gradually cracked open the door to eucharistic communion between Protestants and Catholics stalled. The election of John Paul II in 1978 brought a more traditionalist theological and ecumenical vision to the Curia, calling Catholic theologians in societies like the CTS and CTSA to understand their academic work as connected to "the heart of the Church." 48 In 1983, the Code of Canon Law omitted the words "for a prolonged period" from the condition for extraordinary eucharistic communion, which was followed by the 1995 papal encyclical Ut Unum Sint, which omitted the reference to no access to one's sacramental community, thus obscuring the condition for intercommunion and leaving new legal questions unresolved. ${ }^{49}$ Conciliar centrists like Dulles leaned more in the theological direction of John Paul II. The new Catholic Catechism issued in 1992, which represented this new theological vision, states that eucharistic intercommunion with churches of the Reformation "is not possible"

which included the Dulles essay "Unmasking Secret Infidelities: Hartford and the Future of Ecumenism," 44-62.

47 Patrick W. Carey, Avery Cardinal Dulles, SJ: A Model Theologian, 1918-2008 (Mahwah, NJ: Paulist Press, 2010), 281-94.

${ }^{48}$ John Paul II, Apostolic Constitution on Catholic Universities (Ex Corde Ecclesiae), August 15, 1990, http://w2.vatican.va/content/john-paul-ii/en/apost_constitutions/documents/ hf_jp-ii_apc_15081990_ex-corde-ecclesiae.html.

49 John Paul II, Encyclical, Ut Unum Sint, May 25, 1995, http://w2.vatican.va/content/johnpaul-ii/en/encyclicals/documents/hf_jp-ii_enc_25051995_ut-unum-sint.html. 
because they have not preserved the reality and fullness of the eucharistic mystery because they have not preserved the historic succession of apostolic ministry. ${ }^{50}$ The Catechism does not elaborate on possible exceptional cases when Protestants may in fact be communed.

The PCPCU updated the Ecumenical Directory in 1993, one year after the publication of the new Catechism. ${ }^{51}$ Matters of communion between Catholics and other baptized Christians, including sacramental sharing, were addressed in section IV. The exception for Orthodox communion was continued from the earlier version (IV.B.130). The four conditions under which a Catholic minister may administer the Eucharist to other baptized Christians remained essentially the same as in the earlier edition: (1) no recourse to sacramental communion in his or her own church or ecclesial community, (2) request for the sacrament of his or her own initiative, (3) manifestation of Catholic faith in the sacrament, and (4) proper disposition (IV.B.131). There are two notable changes from the 1967 Ecumenical Directory. One change limits the circumstances in which the Catholic Eucharist may be extended to non-Catholics. The earlier version referred to cases of "urgent need" such as the danger of death, persecution, or imprisonment. The revised version mentions only the danger of death as a circumstance under which non-Catholics may be communed (IV.B.130). It does not preclude the possibility of other cases for exceptional eucharistic sharing, and the determination of those cases is still left to the prudential judgment of local bishops. There is a second change, however, which limits local episcopal oversight. It stipulates that bishops must take into account any general norms that have been established by the episcopal conference for judging situations of "grave and pressing need" and for verifying the four conditions. The changes, though slight, signal the intention of the PCPCU to tighten the rules and restrict the possibilities of exceptional communion of non-Catholic Christians.

\section{Eucharistic Sharing without Breaking the Rules}

Where does this leave us regarding the question with which we began about whether Baptists (and specifically Baptists in the NABPR convention with the CTS) could share eucharistic communion with Catholics without breaking the rules? It is not clear that when McClendon was communed in

${ }^{50}$ Catechism of the Catholic Church, $\$ 1400$ (New York: Doubleday, 1995), 392.

${ }^{51}$ Pontifical Council for Promoting Christian Unity, Directory for the Application of Principles and Norms on Ecumenism, March 25, 1993, http://www.vatican.va/roman_curia/pontifical_councils/chrstuni/documents/rc_pc_chrstuni_doc_25031993_principlesand-norms-on-ecumenism_en.html. 
1996 the rules were kept, at least not the Catholic rules. While he may have met all the exceptional conditions, the local bishop was not involved in the prudential judgment to allow his communion. So it is fairly certain that the rules for Catholic communion were broken, although no doubt he would surely have argued that these rules are extrinsic to, not constitutive of, the observance of the Eucharist. He would have contended that these were guiding principles and that they were the sort of rules that sometimes may need to be broken. Indeed, by the admission of the PCPCU the conditions of the Ecumenical Directory are guidelines for prudential judgments, not immutable ecumenical rules.

Moreover, it is clear from the discussion above that it is unlikely Catholics would be inclined to attend a Baptist observance of the Lord's Supper without significant changes in ecumenical practice. To do so would run into the conflict that Catholic discipline does not regard Baptist ministers, who would presumably be celebrating (or co-celebrating), to be validly ordained, and thus the observance would not be a valid Eucharist. Still it might be worth considering for the Baptists to celebrate a Lord's Supper on Friday and let the Catholics know that they would be welcome to present themselves for a blessing or communion, noting that Catholic discipline does not permit the latter, but that NABPR members would likely in fact meet the substantial Catholic conditions set out for intercommunion.

It also seems possible that within the context of the NABPR/CTS annual convention Baptists might be admitted to commune in the Catholic Eucharist that occurs on Saturday evening during the Mass. But how would such communion be justified? The key consideration, it would seem, is to make the case that this situation fits the circumstances for extraordinary communion. While the two-decade partnership between the CTS and NABPR does not qualify as death, persecution, or imprisonment, it does seem more of a match to the circumstance from the 1972 Instruction on Admitting Other Christians to Eucharistic Communion, which named serious spiritual need for the eucharistic sustenance as an exceptional circumstance. The fact that the CTS convention is held in a different location every year means that the Eucharist falls under the supervision of different diocesan bishops. If it were known, for example, that a particular bishop in whose diocese the CTS planned to meet might be open to considering such an extraordinary sacramental communion, or if a diocese or religious order in which the CTS planned to meet had guidelines for determining situations of "grave and pressing need" that might be seen as receptive to an exceptional case such as ours, then it might be prudent to have those conversations beforehand. It might also be important for Baptists and Catholics to talk with one another about what constitutes (1) lack of recourse to a sacramental 
community, (2) voluntary request, (3) sacramental faith, and (4) proper disposition. Determination of whether these conditions pertain and are satisfied, however, cannot be ascertained prescriptively by simply appealing to these conditions as if they were a set of immutable rules. Rather, their fitness must be discerned in conversation under the guidance of the local bishop (or perhaps the head of a religious order). ${ }^{52}$

As Sandra Yocum reminded us several years ago in her CTS presidential address, the penitent abstention from the table by the Baptists over two decades is a bitter reminder of our brokenness. ${ }^{53}$ We have all been baptized into one body-the Body of Christ-Catholics and Baptists alike, so that we are one with Christ and one with each other in Christ (1 Cor 12:13). Yet we are not permitted to manifest our baptismal unity, nor to receive the healing grace that comes from sacramental sharing. We all have a yearning desire, which comes from a place of deep pain, though we realize that naming it is impossible, for our groaning is too deep for words (Rom 8:26). And so we pray for the Spirit to intercede, and to bear witness that we are children of God, sisters and brothers with one another, members of God's family, heirs of God, and joint heirs with Christ, in his suffering and some day in his glory (Rom 8:16-17). But now, in the suffering of this present time, with one another and with all creation, we wait for the glory that is to be revealed (Rom 8:18-19). And we ask, the Lord willing, that before then, our suffering might be eased.

CURTIS W. FREEMAN

Duke University Divinity School

\section{Serious Spiritual Need?}

Professor Freeman points out that in 1972 the Secretariat for the Promotion of Christian Unity issued the Instruction on Admitting Other

\footnotetext{
52 For an excellent summary of Catholic teaching on intercommunion, see Eoin De Bhaldraithe, "Intercommunion," Heythrop Journal 43, no. 1 (2002): 76-80.

53 See note 1.
}

Timothy Brunk, PhD, is Associate Professor of Theology at Villanova University. His work in sacramental theology is characterized especially by an interest in how sacramental worship and ethical practice mutually inform one another. He has published articles in Worship, Liturgical Ministry, and Qauestions liturgiques. He is currently at work on a book treating sacramental worship and consumer culture. He also serves as a Convener of the Philadelphia Liturgical Institute. 